\title{
Effect of Blended NPS Fertilizer Rates on Growth Performance of Tomato (Solanum lycopersicum L) at Wolaita Sodo University, Ethiopia
}

\author{
Yitbarek Abrham Geletaw Kebede \\ College of Agriculture, Department of horticulture, Wolaita Sodo University, \\ P.O.BOX: 138, Wolaita Sodo, Ethiopia
}

\begin{abstract}
Filed experiment was conducted as Wolaita sodo University, college of agriculture and department of horticulture filed site to evaluate the response of vegetative growth of tomato to different rate of NPS application. The size of total plot is $7.5 \mathrm{~m} \mathrm{X} 5.5 \mathrm{~m}\left(41.25 \mathrm{~m}^{2}\right)$ and the size of each plot was $1.50 \mathrm{~m} \mathrm{X} 1.50 \mathrm{~m}\left(2.25 \mathrm{~m}^{2}\right)$. Three rate of blended NPS fertilizer at $80 \mathrm{~kg} / \mathrm{ha}, 160 \mathrm{~kg} / \mathrm{ha}$ and $240 \mathrm{~kg} / \mathrm{ha}$ with control (check). The experiment was lay out with 12 plots having 3 blokes and each block have four plots. The data on plant height per plant, the primary branches per plant, and the number of leaves per plants were collected from three plants of the middle rows of each plot and subjected to statistical analysis using ANOVA with computing the treatment by least significance difference at $5 \%$. As the result the number of leaf number shows significant $(\mathrm{P}<0.05)$ and the plant height per plant shows significant difference $(\mathrm{P}<\mathrm{O} .5)$ and the others parameters which is the number of primary branch shows non-significant $(\mathrm{p}>0.05)$ different. This shows the tomato crop requires high amount NPS supply enough to maintain the branch, plant height, and the leaf number of tomato vegetative growth. Application of $240 \mathrm{~kg} / \mathrm{ha}$ of blended NPS fertilizer did showed significant factors for all growth parameters. Hence, as this research revealed that application of $240 \mathrm{~kg} / \mathrm{ha}$ was the optimum level for effective vegetative performance of tomato. However, to come up concrete recommendation the study should be repeated across the season and up to yield .
\end{abstract}

Keywords: Tomato, blended NPS fertilizer, Plant height, Leaf number, branch number

DOI: $10.7176 /$ JNSR/9-24-01

Publication date: December $31^{\text {st }} 2019$

\section{INTRODUCTION}

\subsection{Back Ground of the Study}

Tomato (Solanum lycopersicum L) belongs to the solanacea family and it is originated in Peru and ecodor area and was introduced to Central America and México (Sims, 1980, Narvey et al 2002).

It is warm season crop optimum temperature for growth is $21-24$ and also temperature for germination 2630.Tomato requires adequate amount of moisture. Highest production is usually achieved on a well-drained loamy soil (Heuvelink, 1989).

eavelink,2014).It also processed valuable medicinal properties, and excellent purified of blood and reach source vitamin A and C flavored anti-ox The cultivated tomato was brought to Europe to southern and eastern Asia, Africa and Middle East (Shankar, 2005). There is no definite time recorded regarding the introduction of cultivated tomato in Ethiopia. As processing crop, it ranks first amount all vegetable in the world. Their popularity steam from the fact that they can be eaten fresh or in a multiple of processed forms. Three major processed products are ,tomato preserved(whole pealed tomato ,2,dried tomatoes(powder, tomato flakes dried tomato),3,tomato based foods (tomato soup, tomato souce, chilisouces,kitchop)(Costa and Hidant than other vegetables (Heuvelink, 1989).

In Ethiopia tomato grown commercially at all 700-2000m an s 1 with warm and dry and cool nights.specing of tomato is different areas. In Ethiopia tomato can be grown farmers use spacing in $80 \mathrm{~cm} * 30 \mathrm{~cm}$ (Kinet and reet, 1997).

In Ethiopia resently,has expanded to commercial production for home use ,export and processing industries farmers are inserted in tomato production more than any other vegetable for its multiple harvest, which result in high yield and profit per unit area. it is important cash generating to small scale farmers and provide employment in the production and processing industries (June Z.R, 1987). which are mainly used for production of high value vegetable , and tomato is one of the major crops widely cultivated and planting technique used in different part of the country and also where around the world (Lemma ,1998).

The climatic and soil condition of Ethiopia allow cultivation of wide range of fruit and vegetable crops including tomato. It is also grown in large part of eastern and central part mid to low land areas of the country. large scale production is being carried out in the upper awash valley, under irrigated and rain fall condition where as small scale production for fresh market is acommen practice.

Tomato cultivation can be classified by whether the plant is growing out dourer or under protection. Whether the plants are transplanted or direct seeded(Villoreal,1980). since the transplanting first struck the western united states in the late 1990s.many crops in that country are grown exclusively with the use of transplant while others 
are slowly making the transplant while other to direct sowing as growers discovers potential advantage (Katz,2002).tomatoes are usually planted as seedling (also called transplant).most of the world's tomatoes comes from transplanted ,supported plants grown out door (villareal ,1980)

In central rift valley of Ethiopia ,bulk of tomatoes is produced on small scale farmers field, however the lack enough knowledge and skill about appropriate cultural practices good seedling raising method and effective seedling growing media are among the big problems which resulted in poor seedling and poor stand in the field and so lower yield. The usually seed bed used for seedling rising has no good physic-chemical properties of soil. This is because farmers are using only chemical fertilizer year after years, and they consider that the yield obtained from different tomato varieties is the same.

Since farmers cannot got enough comments of vegetable such as tomato seed they proper to transplant any seedling including slender and weaker seedling (Katz, 2002)

The global production of tomato(fresh and processed)has increased by about 30 -in the last four decades the annual worldwide production of tomato in 2003 has been estimated 110 million /ha(FAO/USDA,2003).

Tomato is one of the most popular and widely grown vegetable crops in the world. The tomato crop is highly responsive to nitrogen fertilizer application where nitrogen availability may be limited and time of the application is critical (Taber, 2001).Nitrogen is one of the major elements for plant growth and development that have an important role in plant nutrition and there for is the yield -limiting factor for plant growth in low organic soil. Nitrogen often are mobility in soils and ground water .therefore, management nitrogen fertilizer such as rate type of nitrogen fertilizer, application time is very important (Tens, 2007).

\section{Statementofproblem}

Tomato is cultivated in Ethiopia in most parts of the country throughout the year., incidences of pests and diseases, moisture stress, improper rates of fertilizer application and too high and/or too low temperatures significantly constrain production and productivity of the crop (Getachew and Mohammed, 2012, unpublished).

Among those factors applications of NPS fertilizers are depend mainly on soil condition and have a significant effect relationship with vegetative Growth. The level of NPS fertilizer is very determined to optimum growth of Tomato based on this problems this experiment was conducted to revel the following objectives.

\subsection{Objectives}

\subsubsection{General Objective}

$>$ Application of NPS blended fertilizer at different levels to evaluate its' impact on growth performance of tomato

\subsubsection{Specific objectives}

$>$ To assess responses of tomato variety to blended NPS fertilizer rates.

To determine optimum rate of blended NPS fertilizers to enhance growth performance of tomato

\section{LITERATURE REVIEW}

\subsection{Origin and Distribution of Tomato}

Tomato (Lycopersiconesculentum. Mill)belongs to the family solanaceae, is one of the most important, popular and nutritious vegetable in Bangladesh. It is originated in tropical America and ranks third in terms of world, vegetable production. The popularity of tomato and $\backslash$ different products of tomato processing is increasing day by day. It is a nutritious and delicious vegetable used in salads, soups and processed into stable products like ketchup, sauce and juice(Sin,2000).

Tomatoes can grow in temperate and tropical zone. Its fruits are fleshy berry globular to oblate in shape. The immature fruits are green $2^{\text {nd }}$ hairy. Ripe fruits range from yellow, orange to red, it's usually round, smooth or furrowed tomato fruit mature in about 25-30 after fertilization (Shankar 2005).

MOARD (2009) reported that in Ethiopia, tomato is produced in altitude between 100 and 200, which is characterized as warm and dry and cooler night and favorable for optimum growth and development of tomatoes.

\subsection{Effect of Nitrogen on Vegetative Growth of Tomato}

Nitrogen is highly valance and it's in appropriate application to horticultural crops not only contributes towards pollution but also increase the cost of production. It is there for worthwhile to study the nitrogen response on tomato growth and development. Economic situation of the Rowers are major limiting factor affecting nutrients application to soil and to harvest yield potential an area (bellow, 2002).

Nitrogen is one of the most important nutrient affecting the growth, yield and fruit quality of Tomato (Laura, 2012). It is required in large quantity at each growth stage during which $\mathrm{N}$ affects markedly the amount of Rubisco content of plant and therefore photosynthesis.

Nitrogen fertilizer influence leaf number per plant, plant height, fruit number plant, fruit mean weight and total yield and growth of tomato crops (Ruiz and Romero, 1998).studied tomato cultivars and found that cultivars have significant effects on growth buffalo cultivar and Nancy cultivar, respectively had a least and greatest 
performance.

Nitrogen is a vital nutrient and a major yield limiting factor, it is very essential for plant growth and makes up one to four percent of dry matter of the plants. Nitrogen is a component of protein and nucleic acids and when nitrogen is sub optimal growth is reduced (bellow, 2002). Its availability in sufficient quantity throughout the growing season is essential for optimum tomato growth. It also characteristics constitutes element of proteins and also an integral components of many other compounds essential for plant growth processes including chlorophyll and the many enzymes. It also mediates the utilization of phosphorus, potassium and other elements in plant (onasanya a et al 2000).

The optimal amount of the elements in the soil cannot be utilized efficiently if nitrogen is deficient for plants. Increase plant height with respect to increased nitrogen rate indicates maximum vegetative growth of the plant under higher nitrogen availability (kidist, 2013).

These results are in conformity with the results obtained by Akbar et al, (1999) who found that plant height in tomato increased with increase in nitrogen rate. How every in contrast to the result of this study Sedeghi and Bahrani (2002) reported that increase in nitrogen rate had no significant effect on plant height. The discrepancy in the result obtained in this study might be due to the deferent in the range of population stand, soil fertility status and crop varieties used. (Sedaghi and bahani, 2002).

\subsection{Effect of Phosphorous on the Growth of Tomato}

Phosphorus deficiency in tomato can resulted in stunted growth with purple tinge leaves and low fruit yields (John et al., 2004). The idea was also supported by (Parray and Fazing, 2007) as tomato with phosphorus deficient became dwarf and spindled, small and stiff leaves and development of purple tints on the underside of leaves. Developments of brown areas on old leaves that change to yellow and die before maturity due to lack of phosphate translocation are indicators.

A short term experiment was conducted by Kaya and Higgs with tomato cultivars Blizzard, Liber to and Calypso was carried out in a controlled temperature room to investigate the effectiveness of phosphorus $(\mathrm{P})$ and iron (Fe) supplemented in nutrient solution on plant growth at high zinc concentration. Application of supplementary $\mathrm{P}$ and Fe resulted in marked increases in both dry weight and chlorophyll concentrations achieving values not significantly different to the control (FAO,2007).

\subsection{Effect of Sulfur on the Growth of Tomato}

Sulfur is an essential plant nutrient required for the synthesis of the amino acids cysteine and methionine, protein and enzymes. It has been shown to play an important role in yield and quality of crops (Heebnet al., 2006, Pavlista, 2005, Rhoads and Olson, 2000). Sulfur occurs in the soil both as organic and inorganic forms. In most soil over $90 \%$ of $\mathrm{S}$ is in the diverse organic form (Tabatabai, 1984). The majority of plant absorb $\mathrm{S}$ through the root in the inorganic sulfate $\left(\mathrm{SO}_{4}\right)$ form, although limited amount can be absorbed through the leaf stomata as the gas form $\mathrm{SO}_{2}$. It has been suggested that to achieve high yield and to minimize $\mathrm{S}$ leaching, rate of $\mathrm{S}$ fertilizer should be recommended on the basis of available soil $\mathrm{S}$ and crop requirement (Scherer, 2001)

\subsection{Integrated Effect of Nitrogen, Phosphorous and Sulfur on the Growth of Tomato}

Nitrogen fertilizer influence leaf number per plant, plant height, fruit number plant, fruit mean weight and total yield and growth of tomato crops (Ruiz and Romero, 1998).Phosphorus deficiency in tomato can resulted in stunted growth with purple tinge leaves and low fruit yields (John et al., 2004). The idea was also supported by (Parray and Fazing, 2007) as tomato with phosphorus deficient became dwarf and spindled, small and stiff leaves and development of purple tints on the underside of leaves. Sulfur has been shown to play an important role in yield and quality of crops (Heebnet al., 2006, Pavlista, 2005, Rhoads and Olson, 2000). From the combination of NPS fertilizer $\mathrm{N}=19, \mathrm{P}=38, \mathrm{~S}=7$ and the remaining amounts are ingredients. The combinations of NPS fertilizer have a major effect on growth, yield and quality of tomato.

\section{MATERIALS AND METHODS}

\subsection{Description of study}

The experiment will be conducted in Feb., 2019 at Wolaita Sodo University college of Agriculture department of Horticulture demonstration site. It located SNNP region of Ethiopia at distance $390 \mathrm{~km}$ away from Addis Ababa and $145 \mathrm{~km}$ SNNP capital city of Hawassa at 649, 37 E latitude and 36, $57 \mathrm{~S}$ latitude and also altitude of 1800 meters above sea level (m.a.s.l). The maximum and minimum temperature is $20^{\circ} \mathrm{c}$ and $11.4 \mathrm{c}$ respectively and the maximum and minimum rain fall is $91.4 \%$ and $31.2 \%$ respectively. The annual rain fall of the area is estimated to be $1212 \mathrm{~mm}$. The soil of the area is clay loam with a PH of 6.1 . 


\subsection{Experimental material}

The experiment was consist of four treatment, namely $(0,80 \mathrm{~kg}, 160 \mathrm{~kg}, 240 \mathrm{~kg}$ NPS $/ \mathrm{ha})$ combined with three replication.

Tomato variety: Determinate tomato variety terminate with flower cluster and shoot elongation stopping which most farmers prefer over indeterminate type. This is because determinate type cultivars usually mature fruits earlier than indeterminate type, and are especially desirable where the growing season is short and fruit ripening occur almost all at once, better shelf life, better demand in market, high yielding, better diseases and insect pest tolerant, less cost (no cost of staking which is very cost for most poor small scale farmers) and suitable for mechanical harvesting.

\subsection{Experimental design and layout}

The experiment was laid out with Randomized Complete Block Design (RCBD) with three replications. The treatments which consisted of one tomato variety and 4 types of NPS fertilizer will be randomly assigned to each experimental unit or plot.

\subsection{Total experimental plot}

The experimental field was divided into three blocks each containing 4 plots. Each treatment replicated three times and forms 12 experimental plots in total.

The size of each plot is $2.25 \mathrm{~m}^{2}(1.5 \mathrm{~m} \mathrm{x} 1.5 \mathrm{~m})$. Each treatment contained 20 plants in four rows; only the center row was used for data collection. The twelve treatment combinations was randomly assigned to the unit plot of each block so as to allot one treatment combinations only once in each block. A foot path of $0.5 \mathrm{~m}$ and $0.5 \mathrm{~m}$ was left between plots and blocks, respectively. The space between plant and between rows was $30 \mathrm{~cm}$ and $38 \mathrm{~cm}$ respectively. The length and width of our experimental areawas $(7.5 \mathrm{~m}$ and 5.5).then the total area was 41.25 meter square.

\subsubsection{Procedure of research application and Management}

Roma tomato seed was selected for sown in March, 15/ 2019 on a seed bed size of $1.5 \mathrm{mx} 1.5 \mathrm{~m}$. The seed bed was covered with a dry grass until germination took place. Complete germination of the seeds took place within 7-10 days after sowing and seedlings was thinned out at first true leaf stage in order to maintain optimum plant population and to keep them vigorous. Watering and other cultural managements for quality seedling were done whenever necessary. The soil of the experimental field was uniformly prepared one week prior to transplanting.

The whole experimental field was divided into three blocks, each containing 4 plots. Then seedbeds were watered before uprooting the seedlings in order to minimize the potential damage that can be inflicted to the roots.

After thirty seven days old, healthy and uniform tomato seedlings was transplanted in to the field at spacing of $38 \mathrm{~cm}$ between rows and $30 \mathrm{~cm}$ between plants on April 22/ 2019.

\subsection{Data collection}

Data was collected from three plants of two middle rows by excluding two remain rows due to border effect.

3.5. 1 Growth parameters

a) Plant height (cm): the heights of three plants was measured from ground level to the highest point

b) Number of primary branches/plant: this was recorded by counting the number of primary branches on the main stem at final harvest from three selected sample plants per plot. The average or mean was calculated.

c) Leave number: leaves per plant were recorded as a mean from three plants per plot.

\subsection{Data analysis}

Data on growth performance of the tomato variety was subjected to Analysis of variance (ANOVA) through hand calculation (Manual). Finally, significant treatment means was separated through least significance difference (LSD) test.

\section{RESUALT AND DISCUSSTION}

The vegetative growth of the tomato is influenced by many factors increasing together and independently. Among the factor NPS is the major one. In this study, the effect of NPS alone and the result obtain from the analysis of variance for tomato plant height ,number of leaf per plant and the primary branch per plant are presented . 
Table1. Effect of NPS fertilizer rates on plant height, number of leaves per plant and primary branch

\begin{tabular}{lllll}
\hline no & Treatment & Plant height/plant(cm) & Numberof branch /plant & Number of leaf/plant \\
\hline $\mathbf{1}$ & 0KgNPS/ha & 26.66 & 4 & 50.66 \\
$\mathbf{2}$ & 80kgNPS/ha & 33.77 & 5 & 62.33 \\
$\mathbf{3}$ & 160kgNPS/ha & 35.33 & 6 & 72.66 \\
$\mathbf{4}$ & 240kgNPS/ha & 39.996 & 9 & 82 \\
\hline $\mathbf{5}$ & LSD $(0.05)$ & 3.66 & 2.68 & 6.118 \\
$\mathbf{6}$ & CV $(\%)$ & $9.34 \%$ & 19.7 & $8 \%$ \\
\hline
\end{tabular}

\subsection{Plant height}

The result obtain from the analysis of variance shows that plant height of each treatments were statistically significantly different at $(\mathrm{p}>0.05)$. Plant height was significantly $(\mathrm{P}<0.05)$ influenced by different rates of NPS fertilizer (Table 1.). The larger $(39.996 \mathrm{~cm})$ and the shorter $(26.66 \mathrm{~cm})$ plant height were recorded from $240 \mathrm{kgNPS} / \mathrm{ha}$ and $0 \mathrm{kgNPS} / \mathrm{ha}$, respectively. This may be due to increment of NPS fertilizer. the investigation shows that the plant height increase when NPS increases from $80 \mathrm{kgNPS} /$ ha to the $160 \mathrm{kgNPS} / \mathrm{ha}$ and also to $240 \mathrm{kgNPS} / \mathrm{ha}$ which is disagrees with the finding of sadeghi and bahrani (2002) who reported that increase in NPS rate had no significant effect on plant height. These results are in conformity with the results obtained by Akbar et al,. (1999) who found that plant height in tomato increased with increase in NPS rate. but it is agrees with the result of (kidist, 2013) who reported that the increase plant height with respect to Increased NPS application rate indicates maximum vegetative growth of the plants under higher NPS availability.

\subsection{Number of leaf}

The result obtain from the analysis of variance shows that the leaf number of each treatments were statistically significantly different at $(\mathrm{p}>0.05)$. The number of the plant was significantly $(\mathrm{P}<0.05)$ influenced by different rates of NPS fertilizer (Table 1.). The larger (82) and the smaller (50.66) number of leaf were recorded from $240 \mathrm{~kg}$ NPS/ha and $0 \mathrm{kgNPS} /$ ha, respectively. This may be due to increment of NPS fertilizer. Analysis of variance shows that there is statistically significantly difference between different rates of NPS application on number of leafs.

Regarding number of leaf of the crop it shows that the number of leaf of the crop if effected by NPS level. The analysis of variance shows that as NPS amount increases there were increment in number of leaf regardless of the varieties. The highest mean was recorded on $240 \mathrm{kgNPS} / \mathrm{ha}$ and lowest mean is recorded on $80 \mathrm{kgNPS} / \mathrm{ha}$. This is because excess NPS application makes the number of leafs per plant too high.

\subsection{Number of primary branch per plant}

Analysis of variance shows that there is statistically non-significant between different rates of NPS application on number of primary branch.

Even if treatments are statistically not significantly different from each other. There is an increase in primary branch as NPS rate increase. the result is appear with finding of (kidist,2013) who reported that increasing NPS level from $80 \mathrm{kgNPS} /$ ha to $240 \mathrm{kgNPS} /$ ha increases primary branch but the treatments are not significantly different from the other. This with the previous findings that reported that higher rate of NPS promote primary branch, during vegetative development and also helpto maintain functional branch during the vegetative growth.

\section{SAMMARY AND CONCLUSIONS}

Tomato is one of the most popular and widely growth vegetable crops in the world. It is respond well to NPS fertilizer and adequate fertilizer is particularly important in the tomato growing area. The study was conducted to investigate best dosage of NPS for vegetative growth and to recommended level of NPS rate. The experiment was done at the three NPS level rate $(80,160$, and $240 \mathrm{kgNPS} / \mathrm{ha})$ and the control $(0 \mathrm{~kg} / \mathrm{ha})$ by three replication and data were collected on vegetative growth parameters. In the present study application of NPS were significant at $(\mathrm{p}<0.05)$ effect on the number of leaves, and plant height.

Application of $240 \mathrm{~kg} / \mathrm{ha}$ of blended NPS fertilizer did showed significant factors for all growth parameters. Hence, as this research revealed that application of $240 \mathrm{~kg} / \mathrm{ha}$ was the optimum level for effective vegetative performance of tomato. However, to come up concrete recommendation the study should be repeated across the season and up to yield

\section{REFERENCES}

Ceylan S, Mordogan N, Yoldas F, Yagmur B (2009) the effect of nitrogen fertilization on yield,nitrogen accumulation and content of nutrients in the tomato plant. EgeUniversitie ZiraatFakultesiDergisi. 38(23):103-110.

Dufault RJ, Decoteau DR, Garrett JT, Batal KD, Granberry D, Davis JM, Hoyt G, Sanders D (2000) Influence of cover crops and inorganic nitrogen fertilization on tomato and snap Bean production and soil nitrate 
distribution. J. Veg. Crop Prod., 6(2):13

Felipe EF, Casanova 0E (2000) Nitrogen, phosphorus and potassium fertilization in tomato (Lycopersiconesculentum Mill.)inBalluvial bank soils of the Guarico river. Reivista Unellez de CienciayTecnologia, Production Agricola.17(1): 21-44.

FAO (1997) FAO Production Year Book.Basic Data Unit. Statistics Division, FAO. Rome, Italy, 51:125-127.

Kaya C, Higgs D (2001) Growth enhancement by supplementary phosphorus and iron in tomato cultivars grown hydroponically at high zinc. J. Plant Nutri, 24(12):1861-1870

Khalil SA, Noor B, Kausar MA, Muhammad A, Shah SA (2001) Response of tomato to different nitrogen fertilizers alone and in combination with phosphorus and potassium. Sarhad J. Agril., 17(2): 213-217

Manang EZ, Uriyo AP, Singh BR (1982) Effects of fertilizer nitrogen and phosphorous on tomato. Beitriigezurtropischen land wirtschaft and veterinarmediz in Dares Salaam University, Morogoro, Tanzania, 20(3):247-253.

Nanadal JK, Ramesh V, Pandey UC, Vasist R (1998) Effect of phosphorus and potassium on growth yield and quality of tomato. J. Potassium Res.14 (1-4): 44-49.

Rhoads FM, Gardner CS, Mbuya 0S, Queeley GL, Edwards HM (1999) Tomato fertilization, ground cover, and soil nitrate nitrogen movement. Proceedings Florida State Horticultural Society. (1-2):315-319.

Salunkhe DK, Desai BB, NR Bhat (1987)Vegetable and flower seed production. 1st Edn. Agricola Publishing Academy, New Delhi,India.118-119

Sainju UM, Syed R, Singh BP (2001) Evaluating hairy vetch residue as nitrogen fertilizer for tomato in soilless medium. Hort. Sci.36 (1):90-93.-25.

Silva FC, Miranda JRP, A1varenga MAR (2001) Yield and nutrient concentration of tomato plants pruned and grown under high planting density in relation to phosphorus. Gypsum and nitrogen sources.HorticulturaBrasileira.19(1):64-69

Singh K, Kumer S (1969) Effect of nitrogenand phosphorous fertilization on the growth and yield of onion (Allium cepa L). J. Res.Ludhiana.6:764-768

Topeuoglu B, SR Yalcin (1994) Effect of lime and phosphorus on the formation of oxalic acid and on the yield in tomato. Ankara Universities ZiraatFakultesi Yilligi, 44(1/2): 171-181

Xin XY, Hui LJ, Lili H (1997) the effect of N, P.K mixed application on yields and quality of tomato in solar green house. China Veg.4:10-13.

\section{APPENDIX}

Table. 2 ANOVA for plant height

\begin{tabular}{|l|l|l|l|l|l|}
\hline Source of variation & d.f. & SS & MSS & Fcal & F $\alpha(\operatorname{tab}) 5 \%$ \\
\hline Replication & 2 & 4.2307 & 2.115 & 0.211 & 4.76 \\
\hline Treatment & 3 & 274.7809 & 91.594 & $9.124 * *$ & \\
\hline Error & 6 & 60.2354 & 10.039 & & \\
\hline Total & 11 & 339.247 & 103.748 & & \\
\hline
\end{tabular}

** implies highly significantly difference among the treatments

Table. 3 . ANOVA for number of primary branch per plant

\begin{tabular}{|l|l|l|l|l|l|}
\hline Source of variation & $\mathrm{D}, \mathrm{f}$ & $\mathrm{SS}$ & $\mathrm{MSS}$ & Fcal & $\mathrm{F}(\mathrm{tab}) 5 \%$ \\
\hline Replication & 2 & 0.035 & 0.017 & 0.23 & 4.07 \\
\hline Treatment & 3 & 7.35 & 2.45 & $3.3 \mathrm{~ns}$ & \\
\hline Error & 6 & 0.445 & 0.074 & & \\
\hline Total & 11 & 7.8 & & & \\
\hline
\end{tabular}

** implies highly significantly difference among the treatments

Table. 4. ANOVA for number of leaf per plant

\begin{tabular}{|l|l|l|l|l|l|}
\hline Source of variance & D.f & SS & MS & Fcal & F $\alpha($ tab) $5 \%$ \\
\hline Replication & 2 & 34.667 & 17.33 & 0.614 & 4.76 \\
\hline Treatment & 3 & 16.3691 & 545 & $19.3 * *$ & \\
\hline Error & 6 & 169.332 & 28.222 & & \\
\hline Total & 11 & & & & \\
\hline
\end{tabular}

** implies highly significantly difference among the treatments 